\title{
EXAMINING THE RELATIONSHIP BETWEEN FINANCIAL DEVELOPMENT, SUSTAINABLE ECONOMIC OPPORTUNITY AND ECOLOGICAL FOOTPRINT IN SADC COUNTRIES
}

\author{
OlOWU, G. ${ }^{1 *}$ - BeIN, M. ${ }^{1}-$ OlASEHINDE-WILLIAMS, G. ${ }^{2}$ \\ ${ }^{l}$ Faculty of Economics and Administrative Sciences, Cyprus International University Haspolat \\ via Mersin 10, Turkey \\ ${ }^{2}$ Department of Economics, Eastern Mediterranean University, Famagusta \\ via Mersin 10, Turkey \\ *Corresponding author \\ e-mail: olowugbolahan@gmail.com; phone: +90-392-671-1111 (ex 2227); fax +90-392-671-1130
}

(Received $3^{\text {rd }}$ Aug 2018; accepted $28^{\text {th }}$ Sep 2018)

\begin{abstract}
The study empirically investigates the relationship between financial development, sustainable economic opportunity and ecological footprint in Southern African Development Community (SADC) countries. The research was carried out utilizing time series data on financial access (bank branches per 100,000 adults), financial depth (private credit by deposit money banks to GDP), financial efficiency (bank return on equity percentage, after tax), financial stability (bank Z-score), composite index for financial development, ecological footprint indicator and sustainable economic opportunity. Bootstrap panel causality procedure based on meta-analysis in heterogeneous mixed panels was employed to test causal effects. The empirical results indicate the following; (i) causality between financial development, sustainable economic opportunity and ecological footprint varies across countries with different conditions, which leads to the conclusion that SADC countries are heterogeneous in nature, (ii) for the entire panel, financial development causally affects both sustainable economic opportunity and ecological footprint, and (iii) for the entire panel, sustainable economic opportunity causally affects ecological footprint. The findings suggest introduction of modern financial institutions, especially depository and investment institutions that will stimulate financial services and not only provide funds for investments in human and physical capital required to improve sustainable economic opportunity in SADC countries, but also make funds available for research and development of more efficient ecofriendly technologies.
\end{abstract}

Keywords: Africa, bootstrap panel Granger causality test, environment, funds, growth

\section{Introduction}

The main aim of this research is to empirically analyze and find answers to the following questions in relation to Southern African Development Community (SADC) countries; (i) is there any statistically significant causal relationship between financial development, sustainable economic opportunity and ecological footprint in the regional bloc? (ii) is there any statistically significant causal relationship between financial development, sustainable economic opportunity and the ecological footprint in the individual member countries?

The authors believe that finding answers to these questions will aid policy makers in these countries in economic planning, positioning of the countries for opportunities that are sustainable without losing sight of environmental degradation issues.

Crucial to the development of economically sustainable livelihoods strategies is an in-depth understanding of markets and the facilitation of stronger, fairer relationships between government policies in creating development opportunity, for citizens and corporations. A financially viable enterprise should therefore benefit local communities 
today without entirely sacrificing the future environment (Rousseau and Wachtel, 2011; Feng et al., 2018).

Variables of socio-economic growth in recent times generally include two basic components-sustainability and inclusiveness of opportunity (Acemoglu and Wolitzky, 2015). Sustainable economic opportunity is about being commercially viable and attractive to development today, bearing the future in mind. It is the aggregation and transformation of various capitals, from human, natural, produced, and social capital into financial capital as a means of achieving economic development and growth (Mo Ibrahim Foundation, 2018).

Financial development is advancement of financial systems (financial markets, banks and various financial intermediaries) in quality, quantity and efficiency. It is the output of the depth, access and efficiency of the financial sector (Ang and McKibbin, 2007; Huang and Wang, 2017). Countries always put in place policies, institutions, and measures that create, widen and deepen effective financial markets and intermediaries so that capital and financial services can be easily available (World Economic Forum, 2012). Financial capital is often utilized to the detriment of sustainability which is long term. Most financial and commercial activities are usually aimed at short term gains and immediate profit (Sofia et al., 2011).

Ecological footprint is a measurement of how much nature still exists, and how much has been used up. It measures the ecological assets that a given population requires to produce the natural resources it consumes. It is an extensive detailing of demand and supply of nature, in supporting commercial activities. The ecological footprint is an instrument of projection to track the consumption of land and/or living resources and the carbon-based waste of human populations (Baabou et al., 2017; Global Footprint Network, 2018).

Over the past two decades, extant literature has revealed that financial sector activities and environmental resources have significant impact on economic performance of societies ( $\mathrm{Li}$ et al., 2016). Unsurprisingly, research interest in this area continues to grow. An extensive body of literature exists on the inter-relations between financial development and economic activity. They are grouped into 4 broad categories; (i) those that provide evidence in support of the supply-leading theory which states that economic growth is preceded by financial development. The theory suggests that financial development induces improvements in savings and investment efficiency which in turn drives economic growth (Ang, 2008; Körner and Schnabel, 2009; Bojanic, 2012; Pradhan et al., 2014; Li et al., 2015), (ii) those that support the demand-following theory which states that economic growth drives the demand for financial services. The theory asserts that growth in the real sector of an economy raises the demand for supporting financial services and this in turn induces growth in the financial sector (Liang and Jian-Zhou, 2006; Ang and McKibbin, 2007; Panopoulou, 2009), (iii) those that are in alignment with the neutrality hypothesis. This group of literature posits that there is no significant relationship between the financial sector and economic growth (Al-Yousif, 2002; Mukhopadhyay et al., 2011), and (iv) the group of studies that affirm the existence of a feedback relationship (feedback hypothesis). The feedback hypothesis argues that improved financial sector performance positively affects economic growth and increased economic growth in turn causes an increase in demand for financial services (Wolde-Rufael, 2009; Pradhan et al., 2013).

The economic activity-environment nexus has mostly been tested within the environmental Kuznets curve (EKC) framework which examines the impact of 
economic growth on single pollution indicators such as $\mathrm{CO}_{2}, \mathrm{SO}_{2}, \mathrm{NO}_{\mathrm{X}}$ and $\mathrm{CO}$ and asserts that there is an inverted U-shaped relationship between economic performance and pollution. The hypothesis suggests that pollution increases alongside industrialization during the early stages of economic growth up to a point beyond which higher economic growth leads to the introduction of more efficient technologies, better environmental regulations and higher environmental expenditures (Acar and Asici, 2017). Recent examples of such EKC studies include Lau et al. (2014), Onafowora and Owoye (2014), Al-Mulali et al. (2015), Apergis and Ozturk (2015), Chang (2015), Tang and Tan (2015), Azam and Khan (2016), Kang et al. (2016), Li et al. (2016), and Gill et al. (2017).

Overall, studies on economic activity, financial development and the environment display the following limitations. First, many of them only investigate the effect of either financial development or economic growth on environmental quality. They do not examine all 3 variables within a unified framework. Second, most of the studies only carry out one-way examinations of the effect of either financial development or economic growth on environmental quality. They mostly neglect the possibility of feedback relationships. Third, most of them adopt very narrow measures of these 3 variables. For example, financial development is mostly proxied with these three measures: domestic credit to private sector, banking sector credit and financial domestic credit. These measures of financial development are indicators of financial depth. They ignore other important aspects of financial sector performance such as financial access, financial efficiency and financial stability. Similarly, environmental quality is mostly measured with degree of pollution. However, the impacts of economic activities are wide-ranging and multidimensional, such that it cannot be sufficiently accounted for using one-dimensional pollution indicators (Wackernagel et al., 2002). Also, economic performance is most commonly measured through economic growth which largely ignores economic opportunities that contribute to a prosperous and equitable society. Finally, previous studies also mostly neglect the issues of cross-sectional dependency and cross-country heterogeneity. According to Chang et al. (2013), the importance of cross-country heterogeneity and cross-sectional dependency cannot be over emphasized. Although each country may sustain its own dynamics in economic development, economic or financial instability in one country often spreads to other countries through economic integration and trade.

In this context, this study's contributions to literature are as follows. First, the relationship between financial development, economic performance and the environment is examined via bootstrap panel Granger causality tests of Emirmahmutoglu and Kose (2011) in SADC countries. With this test, it is possible to detect Granger causality in the entire panel as well as in each of the individual countries contained in the panel. Furthermore, with this test, the pre-test bias associated with testing for stationarity and co-integration is avoided. Second, panel causality modeling which controls for country-specific differences and cross-country dependency is followed. Third, various dimensions of financial development-financial access, financial depth, financial efficiency and financial stability-as well as an aggregate index of these 4 measures is considered. Moreover, ecological footprint, a multidimensional indicator of environmental state, is used in this study. Furthermore, rather than adopt economic growth as the measure of economic performance, the degree of sustainable economic opportunity is used instead. 


\section{SADC countries}

Southern African Development Community (SADC) consists of 15 countries whose main objectives are; achievement of development and economic growth, poverty alleviation, enhancement of standard and quality of life through regional integration, evolution of common political values, systems and institutions, promotion of peace and security, promotion of self-sustaining development on the basis of collective selfreliance and interdependence among Member States, achievement of complementarity between national and regional strategies and programmes, maximization of productive employment and utilization of resources of the Region, achievement of sustainable utilization of natural resources and effective protection of the environment, and consolidation of the long standing historical, social and cultural affinities and links among the people of the Region.

The sources of GDP in SADC are industry (32\%), agriculture (17\%), and service sector, with the largest share (52\%). This regional bloc has shown signs of economic improvement over the past decade. The regional bloc includes four countries officially classified as middle-income countries-Botswana, Mauritius, Namibia and South Africa (www.sadc.int/about-sadc/overview/sadc-facts-figures).

The rest of this study is structured as follows: data and empirical methodology, results, discussions and conclusion.

\section{Data and empirical methodology}

\section{Data}

The study sample consists of time series data on 13 of the 15 SADC countries over the period 2000-2016. Seychelles and Zimbabwe are left out of the sample due to insufficient data. In the analysis, data on financial access (bank branches per 100,000 adults), financial depth (private credit by deposit money banks to GDP), financial efficiency (bank returns on equity \%, after tax) and financial stability (bank Z-score) provided by the World Bank and accessed at http://www.worldbank.org/en/publication/gfdr/data/global-financial-development-

database are used. These 4 measures are then further aggregated into a single composite index for financial development using principal component analysis (PCA) given as (Eq. 1):

$$
p_{i}=\sum_{i=1}^{n} a_{i j} x_{i}
$$

where: $p_{i}=p_{1}, p_{2}, \ldots, p_{k}$ represent the principal Components, $a_{i j}$ stand for component loadings and $x$ refers to the original measures. Differences in measurement units were controlled for by using the variables in their standardized forms. The composite index is constructed with the formula (Eq. 2):

$$
C I=\sum_{i=1}^{n} a_{i j} \frac{x_{i j}}{\sigma(x)_{i}}
$$

where: $\mathrm{CI}$ is the composite index for financial development and $\sigma$ is the standard deviation. 
The ecological footprint indicator provided by (Global Footprint Network, 2018) is used as the measure of environment condition. Ecological footprint sums the use of six categories of productive surface areas: cropland, grazing land, fishing grounds, built-up land, forest area, and carbon demand on land and land area. It is expressed in units of global hectares (gha).

Data on sustainable economic opportunity is from the Ibrahim Index of African Governance (IIAG) online database. The sustainable economic opportunity index consists of four sub-categories (public management, business environment, infrastructure and rural sector), made up of 29 indicators, from 18 different data sources.

The descriptive statistics for the SADC countries included in the analysis are presented in Table 1.

Table 1. Summary statistics

\begin{tabular}{|c|c|c|c|c|}
\hline \multicolumn{5}{|c|}{ Panel A: Financial development index } \\
\hline Country & Mean & Std. Dev & Minimum & Maximum \\
\hline Angola & 11.589 & 1.237 & 9.278 & 14.155 \\
\hline Botswana & 9.136 & 1.545 & 6.150 & 11.260 \\
\hline DR Congo & 5.037 & 1.333 & 3.120 & 9.2700 \\
\hline Lesotho & 7.886 & 0.847 & 5.960 & 9.2800 \\
\hline Madagascar & 5.552 & 0.745 & 4.200 & 6.9400 \\
\hline Malawi & 9.691 & 1.093 & 8.350 & 12.060 \\
\hline Mauritius & 18.184 & 4.334 & 11.390 & 27.610 \\
\hline Mozambique & 3.629 & 1.175 & 2.640 & 7.4100 \\
\hline Namibia & 17.621 & 15.769 & 7.530 & 45.210 \\
\hline South Africa & 16.153 & 7.366 & 11.360 & 40.040 \\
\hline Swaziland & 14.554 & 4.005 & 5.4600 & 18.280 \\
\hline Tanzania & 10.606 & 1.500 & 8.8200 & 13.820 \\
\hline Zambia & 2.252 & 0.379 & 1.763 & 3.131 \\
\hline Panel & 10.121 & 7.110 & 1.763 & 45.210 \\
\hline \multicolumn{5}{|c|}{ Panel B: Sustainable economic opportunity } \\
\hline Angola & 28.093 & 3.575 & 23.400 & 32.700 \\
\hline Botswana & 66.237 & 1.935 & 63.300 & 68.800 \\
\hline DR Congo & 28.862 & 3.396 & 24.200 & 35.100 \\
\hline Lesotho & 47.387 & 1.860 & 44.500 & 50.300 \\
\hline Madagascar & 42.525 & 3.084 & 36.300 & 47.500 \\
\hline Malawi & 48.126 & 2.336 & 45.500 & 52.000 \\
\hline Mauritius & 72.380 & 5.654 & 66.600 & 79.900 \\
\hline Mozambique & 46.640 & 1.790 & 44.100 & 49.900 \\
\hline Namibia & 60.600 & 2.357 & 57.500 & 63.800 \\
\hline South Africa & 66.206 & 2.574 & 62.400 & 69.300 \\
\hline Swaziland & 46.340 & 3.408 & 41.800 & 50.700 \\
\hline Tanzania & 50.133 & 1.506 & 46.100 & 52.500 \\
\hline Zambia & 48.493 & 1.690 & 45.700 & 51.700 \\
\hline Panel & 50.209 & 13.288 & 23.400 & 79.900 \\
\hline
\end{tabular}




\begin{tabular}{c|l|l|l|l}
\hline \multicolumn{5}{c}{ Panel C: Ecological footprint } \\
\hline Angola & 0.600 & 0.191 & 0.410 & 0.980 \\
Botswana & 1.702 & 0.174 & 1.360 & 2.040 \\
DR Congo & 0.465 & 0.015 & 0.430 & 0.480 \\
Lesotho & 0.903 & 0.046 & 0.830 & 0.990 \\
Madagascar & 0.594 & 0.026 & 0.540 & 0.640 \\
Malawi & 0.444 & 0.046 & 0.360 & 0.510 \\
Mauritius & 1.754 & 0.212 & 1.400 & 2.080 \\
Mozambique & 0.486 & 0.049 & 0.430 & 0.600 \\
Namibia & 2.829 & 0.979 & 1.898 & 5.702 \\
South Africa & 1.957 & 0.141 & 1.660 & 2.170 \\
Swaziland & 1.216 & 0.254 & 0.660 & 1.450 \\
Tanzania & 0.722 & 0.066 & 0.660 & 0.870 \\
Zambia & 0.495 & 0.057 & 0.430 & 0.590 \\
Panel & 1.094 & 0.782 & 0.360 & 5.702
\end{tabular}

In Table 1, the lowest mean financial development value (2.252) reported for Zambia shows the country has the least developed financial sector over the period considered, and the highest mean financial development value (18.184) reported for Mauritius indicates the country has the best developed financial sector for the period considered. Mauritius again turns out as the best performing country in terms of sustainable economic opportunity (72.380) while Angola has the poorest performance (28.093). Average demand of nature is highest in Namibia (2.829) and lowest in Malawi (0.444).

\section{Methodology}

\section{Bootstrap panel Granger casualty test}

This study applies the bootstrap panel causality procedure based on meta-analysis in heterogeneous mixed panels proposed by Emirmahmutoglu and Kose (2011). The test is an extension of the Toda and Yamamoto (1995) approach to testing coefficient restrictions in a level VAR model for an integrated or cointegrated process. The test does not require the variables in the underlying VAR system to be stationary. It may therefore be applied to panels consisting of stationary, non-stationary, cointegrated and non-cointegrated series (Seyoum et al., 2014). Pre-test bias associated with testing for stationarity and cointegration is therefore avoided. The method employs a modified Wald (MWALD) test in a lag augmented VAR (LA-VAR) which has a conventional asymptotic chi-square distribution when a VAR $(p+d m a x)$ is estimated, where $p$ is the lag order and dmax is the maximal order of integration suspected to occur in the process. The system of equations for the panel causality tests include two sets of equations specified as follows:

$$
\begin{aligned}
& Y_{1, t}=a_{1, i}+\sum_{i=1}^{i y_{1}+d m a x x_{j}} \beta_{1, i, j} Y_{1, t-i}+\sum_{i=1}^{i x_{1}+d m a x x_{j}} \delta_{1,1, i} X_{1, t-i}+\sum_{i=1}^{i x_{1}+d m a x x_{j}} \gamma_{1,1, i} Z_{1, t-i}+\varepsilon_{1,1, t} \quad \text { (Eq.1a) } \\
& Y_{2, t}=a_{1,2}+\sum_{i=1}^{i y_{1}+d \max j_{j}} \beta_{1,2, i, j} Y_{2, t-i}+\sum_{i=1}^{i x_{1}+d \max _{j}} \delta_{1,2, i} X_{2, t-i}+\sum_{i=1}^{i x_{1}+d m a x_{j}} \gamma_{1,2, i} Z_{2, t-i}+\varepsilon_{1,2, t} \quad \text { (Eq.1b) }
\end{aligned}
$$




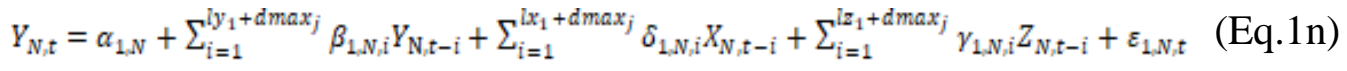

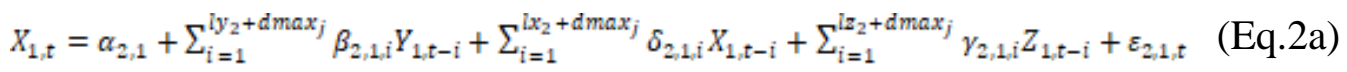

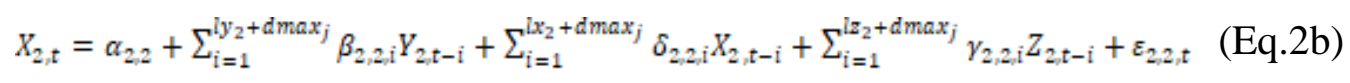

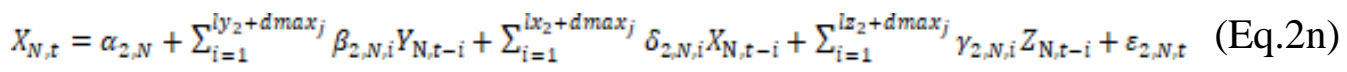

and

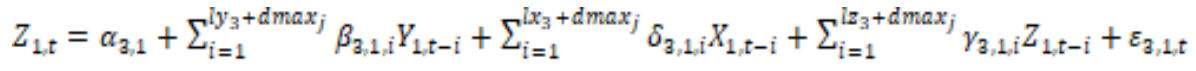

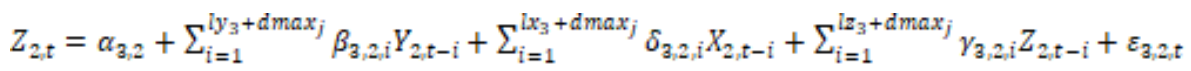

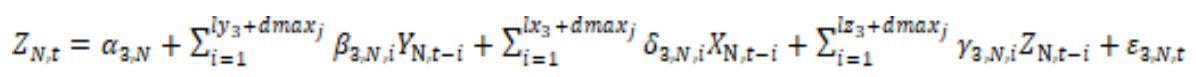

In the system of Equations 1, 2 and 3, $\mathrm{Y}_{\mathrm{i}, \mathrm{t}}, \mathrm{i}=1, \ldots, \mathrm{N}$ denotes financial development (access, depth, efficiency, stability and overall index, respectively), $\mathrm{X}_{\mathrm{i}, \mathrm{t}}, \mathrm{i}=1, \ldots, \mathrm{N}$ denotes sustainable economic opportunity and $\mathrm{N}$ represents the number of countries included in the panel $(j=1, \ldots, N), Z_{i, t}, i=1, \ldots, N$ is ecological footprint. $t$ refers to the time period $(t=1, \ldots, T), 1$ is the lag length and $\operatorname{dmax}_{j}$ stands for the maximal order of integration.

The possible alternative causal relations that could be detected for each country and the entire panel are (i) One-way Granger causality from $\mathrm{X}$ to $\mathrm{Y}$ when all $\beta_{2, \mathrm{j}, \mathrm{i}} \mathrm{S}$ are zero, but not all $\delta_{1, \mathrm{j}, \mathrm{S}}$ are zero. (ii) One-way Granger causality from $\mathrm{Y}$ to $\mathrm{X}$ when all $\delta_{1, \mathrm{j}, \mathrm{i}} \mathrm{S}$ are zero, but not all $\beta_{2, \mathrm{j}, \mathrm{iS}}$ are zero. (iii) Two-way Granger causality between $\mathrm{X}$ and $\mathrm{Y}$ if some of the $\delta_{1, \mathrm{j}, \mathrm{i}}$ and $\beta_{2, \mathrm{j}, \mathrm{i}}$ are not zero. (iv) One-way Granger causality from $\mathrm{Z}$ to $\mathrm{Y}$ when all $\beta_{3, j, i s}$ are zero, but not all $\gamma_{1, j, i s}$ are zero. (v) One-way Granger causality from $\mathrm{Y}$ to $\mathrm{Z}$ when all $\mathrm{\gamma}_{1, \mathrm{j}, \mathrm{i}}$ are zero, but not all $\beta_{3, \mathrm{j}, \mathrm{i}}$ are zero. (vi) Two-way Granger causality between $Z$ and $Y$ if some of the $\gamma_{1, j, i}$ and $\beta_{3, j, j}$ are not zero. (vii) One-way Granger causality from $Z$ to $X$ when all $\delta_{3, j}$, is are zero, but not all $\gamma_{2, j, i}$ are zero. (viii) One-way Granger causality from $X$ to $Z$ when all $\gamma_{2, \mathrm{j}, \mathrm{i}}$ are zero, but not all $\delta_{3, \mathrm{j}, \mathrm{i}}$ are zero. (ix) Two-way Granger causality between $Z$ and $X$ if some of the $V_{2, j, i}$ and $\delta_{3, j, i s}$ are not zero.

The Emirmahmutoglu and Kose (2011) Granger causality test employs the Fisher (1932) meta-analysis statistical procedure. It conducts $\mathrm{N}$ number of separate time series tests, and combines the significant individual $\mathrm{p}$-values in a single panel test statistic. The test statistic has a chi-square distribution with $2 \mathrm{~N}$ degrees of freedom. The Fisher test statistic $(\lambda)$ is specified as $(E q .4)$ :

$$
\lambda=-2 \sum_{\mathrm{i}=1}^{\mathbb{N}} \ln _{\text {(pi) }} i=1,2, \ldots, N
$$

pi denotes the p-value for the Wald statistic of the ith cross section.

In the presence of cross sectional dependency, the limit distribution of the Fisher test statistic becomes invalid. The test deals with this problem through the bootstrap approach. Readers are referred to Emirmahmutoglu and Kose (2011) for the detailed 
bootstrap procedure. In line with Emirmahmutoglu and Kose (2011), Equations 1, 2 and 3 are estimated and the panel Granger causality tests with bootstrap critical values are executed (Eq. 5).

$$
L M=\sum_{i=1}^{N-1} \sum_{j=i+1}^{N} T_{i j} \hat{p}_{i j}^{2} \rightarrow \chi^{2} \frac{N(N-1)}{2}
$$

where $\hat{p}_{i j}^{2}=$ correlation coefficients from residuals

Pesaran (2004) Scaled LM test: Pesaran (2004) developed a scaled version of the LM test which is more efficient than the Breusch-Pagan (1980) LM test for data series with large N. Under the null of no cross-sectional dependence, the LM statistic is as follows (Eq. 6):

$$
L M_{s}=\sqrt{\frac{1}{N(N-1)}} \Sigma_{i=1}^{N-1} \sum_{j=i+1}^{W}\left(T_{i j} \hat{p}_{i j}^{2}-1\right) \rightarrow N(0,1)
$$

Pesaran (2004) CD test: a major flaw of the previous tests is that they suffer from size distortion especially when $\mathrm{N}$ is large and $\mathrm{T}$ is small. To deal with this limitation, Pesaran (2004) developed a more general alternative test statistic that provides valid results for large panels by averaging pairwise correlation coefficients $\hat{p}_{i j}$. For the null of no cross-sectional dependence, the LM test statistic for dependence is given as (Eq. 7):

$$
C D_{p}=\sqrt{\frac{2}{N(N-1)}} \sum_{i=1}^{N-1} \sum_{j=i+1}^{N} T_{i j} \hat{p}_{i j} \rightarrow N(0,1)
$$

\section{Tests for slope homogeneity}

Cross-country heterogeneity is also an issue of importance when employing bootstrap panel causality tests. Presence of slope heterogeneity in the data series is an indication that economic occurrences observed in one of the SADC countries are not necessarily replicated in the other SADC countries. The Pesaran and Yamagata (2008) standardized version of the Swamy (1970) homogeneity test was applied. The modified version of the Swamy (1970) test is computed as (Eq. 8):

$$
S=\sum_{i=1}^{N}\left(\hat{\beta}_{i}-\hat{\beta}_{W F E}\right)^{r} X_{I}^{g} \frac{M_{i} X_{i}}{\sigma_{i}^{2}}\left(\hat{\beta}_{i}-\hat{\beta}_{W F E}\right)
$$

where $\hat{\beta}_{i}=$ Pooled OLS estimator, $\hat{\beta}_{W F E}=$ weighted fixed effect pooled estimator and $\tilde{\sigma}_{\bar{i}}^{2}$ is the estimator. The standard dispersion statistics is computed as (Eq. 9):

$$
\widetilde{\Xi}=\sqrt{N}\left(\frac{N^{-1} \xi-k}{2 k}\right)
$$

Alternatively, the bias adjusted version of the standard dispersion statistics may be computed (Eq. 10):

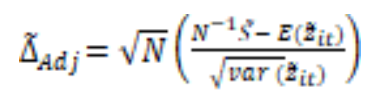

Both statistics are tested under the null of slope homogeneity. 


\section{Results}

Table 2 reports the results of cross-sectional dependence tests $\left(\mathrm{LM}, \mathrm{LM}_{\mathrm{S}}\right.$ and $\left.\mathrm{CD}_{\mathrm{P}}\right)$ obtained from estimating Equations 6, 7 and 8. The results from LM and $\mathrm{LM}_{\mathrm{S}}$ tests clearly show that the null hypothesis of no cross-sectional dependence is rejected for all variables at $(p<0.01)$ significance level, whereas the results from $C_{p}$ test show that the null of no cross-sectional dependence is rejected for depth, stability, financial index and sustainable economic opportunity at $(\mathrm{p}<0.01)$ level of significance, and for access at $(p<0.1)$ level of significance. Both efficiency and ecological footprint turn out as insignificant under the $\mathrm{CD}_{\mathrm{p}}$ test. The results overwhelmingly indicate that there is crosssectional dependence among the SADC countries. Therefore, shocks are transmitted across the SADC economies. Table 2 also reports the results from the slope homogeneity tests $\left(\widehat{\Delta}_{,} \widehat{\Delta}_{a d j}\right)$. Based on the delta and the bias adjusted delta statistics, the null hypothesis of slope homogeneity is rejected for financial depth, financial efficiency, overall financial index, ecological footprint and sustainable economic opportunity. This suggests that individual SADC countries possess unique economic characteristics. The bootstrap panel Granger causality approach can thus be applied.

Table 2. Cross-sectional dependence and homogeneous test results

\begin{tabular}{|c|c|c|c|c|c|}
\hline \multirow{2}{*}{ Variables } & \multicolumn{3}{|c|}{ Cross-sectional dependence tests } & \multicolumn{2}{|c|}{$\begin{array}{c}\text { Slope homogeneity } \\
\text { tests }\end{array}$} \\
\hline & LM (Eq.5) & LMs (Eq.6) & CDp (Eq.7) & $\widehat{\triangle}(\mathbf{E q . 8})$ & $\widehat{\Delta}_{\text {adj }}(\mathbf{E q . 9})$ \\
\hline Access & $194.256^{* * *}$ & $9.308^{* * *}$ & $-1.345^{*}$ & 1.114 & 1.236 \\
\hline Depth & $134.804^{* * *}$ & $4.548^{* * *}$ & $4.874^{* * *}$ & $2.456^{* * *}$ & $2.725^{* * *}$ \\
\hline Efficiency & $135.590^{* * *}$ & $4.611^{* * *}$ & -0.799 & $1.857^{* *}$ & $2.060^{* *}$ \\
\hline Stability & $120.212^{* * *}$ & $3.380^{* * *}$ & $4.441^{* * *}$ & 1.143 & 1.268 \\
\hline Fin. index & $230.785^{* * *}$ & $12.233^{* * *}$ & $3.277^{* * *}$ & $1.199^{*}$ & $1.330^{*}$ \\
\hline Ecological footprint & $123.202^{* * *}$ & $3.619^{* * *}$ & -0.722 & $3.075^{* * *}$ & $3.412^{* * *}$ \\
\hline Sustainable economic opportunity & $125.343^{* * *}$ & $3.790^{* * * *}$ & $-1.843^{* * *}$ & $4.420^{* * *}$ & $4.903^{* * *}$ \\
\hline
\end{tabular}

$*, * *$ and $* * *$ indicate significance at $0.1,0.05$ and 0.001 significance levels, respectively

Tables 3-7 below report the test statistics for the causality tests between financial development (overall index, access, depth, efficiency and stability, respectively) and sustainable economic opportunity for each SADC country, and for the entire panel. The main focus is on the outcomes involving the overall financial index. The test results indicate that at country level, the causality between financial development and sustainable economic opportunity varies across countries with different conditions. For example, significant Granger causality from overall financial development index to sustainable economic opportunity exists in Botswana, Mauritius and Namibia. Significant Granger causality in the other direction exists in DR Congo, Malawi and Mozambique. A significant feedback relationship only exists in South Africa. At the panel level, significant one-way causality is detected running from the overall financial development index to sustainable economic opportunity. 
When the overall index is disaggregated into its components, at the country level, the following results are found. Significant one-way causality from; financial access to sustainable economic opportunity in Botswana, DR Congo, Mauritius, Mozambique, Namibia and South Africa, from sustainable economic opportunity to financial access in Angola, from financial depth to sustainable economic opportunity in Mozambique, South Africa and Swaziland, from sustainable economic opportunity to financial depth in Angola, DR Congo and Tanzania, from financial efficiency to sustainable economic opportunity in Angola, Namibia, South Africa and Swaziland, from sustainable economic opportunity to financial efficiency in Lesotho and Madagascar, from financial stability to sustainable economic opportunity in Botswana, DR Congo, Mauritius, Namibia and South Africa, and from sustainable economic opportunity to financial stability in DR Congo, Lesotho, Malawi, Mozambique and Zambia. Bidirectional causal relationships are however detected between financial access and sustainable economic opportunity in Lesotho, between financial depth and sustainable economic opportunity in Madagascar, Malawi, Mauritius and Namibia, between financial efficiency and sustainable economic opportunity in Malawi and Mozambique, and between financial stability and sustainable economic opportunity in Madagascar, South Africa and Tanzania. At the panel level, significant one-way causality from financial access and financial efficiency to sustainable economic opportunity is found, whereas a significant feedback relationship is detected between financial depth and sustainable economic opportunity and between financial stability and sustainable economic opportunity.

Table 3. Granger causality between financial development (index) and sustainable economic opportunity

\begin{tabular}{|c|c|c|c|}
\hline \multicolumn{2}{|c|}{$\begin{array}{l}\text { H0: financial development (index) does not } \\
\text { Granger cause sustainable economic opportunity }\end{array}$} & \multicolumn{2}{|c|}{$\begin{array}{l}\text { H0: sustainable economic opportunity does not } \\
\text { Granger cause financial development (index) }\end{array}$} \\
\hline Countries & Wald statistic & Countries & Wald statistic \\
\hline Angola & 0.059 & Angola & 2.628 \\
\hline Botswana & $6.999^{* * *}$ & Botswana & 0.062 \\
\hline DR Congo & 0.612 & DR Congo & $28.153^{* * *}$ \\
\hline Lesotho & 2.144 & Lesotho & $2.740^{*}$ \\
\hline Madagascar & 2.339 & Madagascar & 0.879 \\
\hline Malawi & 1.461 & Malawi & $23.596^{* * *}$ \\
\hline Mauritius & $3.646^{* *}$ & Mauritius & 0.098 \\
\hline Mozambique & 0.311 & Mozambique & $41.915^{* * *}$ \\
\hline Namibia & $4.826^{* *}$ & Namibia & 0.245 \\
\hline South Africa & $35.555^{* * *}$ & South Africa & $43.658^{* * *}$ \\
\hline Swaziland & 2.704 & Swaziland & 2.970 \\
\hline Tanzania & 1.161 & Tanzania & 0.182 \\
\hline Zambia & 0.834 & Zambia & 0.022 \\
\hline Panel & $77.256^{* *}$ & Panel & 158.424 \\
\hline
\end{tabular}

$*, * *$ and $* * *$ indicate significance at $0.1,0.05$ and 0.001 significance levels, respectively 


$$
-7181 \text { - }
$$

Table 4. Granger causality between financial development (access) and sustainable economic opportunity

\begin{tabular}{c|c|c|c}
\hline $\begin{array}{c}\text { H0: financial development (access) does not } \\
\text { Granger cause sustainable economic opportunity }\end{array}$ & \multicolumn{2}{|c}{$\begin{array}{c}\text { H0: sustainable economic opportunity does not } \\
\text { Granger cause financial development (access) }\end{array}$} \\
\hline Countries & Wald statistic & Countries & Wald statistic \\
\hline Angola & 0.615 & Angola & $8.265^{* * *}$ \\
Botswana & $6.999^{* * *}$ & Botswana & 0.062 \\
DR Congo & $24.705^{* * *}$ & DR Congo & 4.281 \\
Lesotho & $21.873^{* * *}$ & Lesotho & $7.771^{* * *}$ \\
Madagascar & 2.339 & Madagascar & 0.879 \\
Malawi & 3.963 & Malawi & 0.036 \\
Mauritius & $3.646^{* *}$ & Mauritius & 0.098 \\
Mozambique & $3.496^{* *}$ & Mozambique & 0.541 \\
Namibia & $5.824^{* *}$ & Namibia & 0.189 \\
South Africa & $12.895^{* * *}$ & South Africa & 0.930 \\
Swaziland & $8.155^{* * *}$ & Swaziland & 0.057 \\
Tanzania & 1.161 & Tanzania & 0.182 \\
Zambia & 0.900 & Zambia & 0.076 \\
Panel & $108.526^{* *}$ & Panel & 0.568 \\
\hline
\end{tabular}

$*, * *$ and $* * *$ indicate significance at $0.1,0.05$ and 0.001 significance levels, respectively

Table 5. Granger causality between financial development (depth) and sustainable economic opportunity

\begin{tabular}{c|c|c|c}
\hline $\begin{array}{c}\text { H0: financial development (depth) does not } \\
\text { Granger cause sustainable economic opportunity }\end{array}$ & \multicolumn{2}{|c}{$\begin{array}{c}\text { H0: sustainable economic opportunity does not } \\
\text { Granger cause financial development (depth) }\end{array}$} \\
\hline Countries & Wald statistic & Countries & Wald statistic \\
\hline Angola & 2.925 & Angola & $25.486^{* * *}$ \\
Botswana & 1.386 & Botswana & 1.056 \\
DR Congo & 0.612 & DR Congo & $28.154^{* * *}$ \\
Lesotho & 3.078 & Lesotho & 1.076 \\
Madagascar & $8.685^{* *}$ & Madagascar & $8.467^{* *}$ \\
Malawi & $17.019^{* * *}$ & Malawi & $19.902^{* * *}$ \\
Mauritius & $13.246^{* * *}$ & Mauritius & $30.121^{* * *}$ \\
Mozambique & $4.224^{* * *}$ & Mozambique & 0.551 \\
Namibia & $9.996^{* *}$ & Namibia & $10.829^{* * *}$ \\
South Africa & $7.237^{*}$ & South Africa & 1.748 \\
Swaziland & $16.643^{* * *}$ & Swaziland & 0.271 \\
Tanzania & 6.050 & Tanzania & $11.689^{* * *}$ \\
Zambia & 3.794 & Zambia & 3.589 \\
Panel & $84.040^{*}$ & Panel & $131.834^{* *}$ \\
\hline
\end{tabular}

$*, * *$ and $* * *$ indicate significance at $0.1,0.05$ and 0.001 significance levels, respectively 
Table 6. Granger causality between financial development (efficiency) and sustainable economic opportunity

\begin{tabular}{c|c|c|c}
\hline $\begin{array}{c}\text { Ho: financial development (efficiency) does not } \\
\text { Granger cause sustainable economic opportunity }\end{array}$ & \multicolumn{2}{|c}{$\begin{array}{c}\text { H0: sustainable economic opportunity does not } \\
\text { Granger cause financial development (efficiency) }\end{array}$} \\
\hline Countries & Wald statistic & Countries & Wald statistic \\
\hline Angola & $13.430^{* * *}$ & Angola & 0.404 \\
Botswana & 1.476 & Botswana & 4.676 \\
DR Congo & 1.085 & DR Congo & 2.601 \\
Lesotho & 3.657 & Lesotho & $11.187^{* *}$ \\
Madagascar & 1.755 & Madagascar & $3.679^{*}$ \\
Malawi & $22.468^{* * *}$ & Malawi & $27.576^{* * *}$ \\
Mauritius & 3.154 & Mauritius & 4.538 \\
Mozambique & $7.460^{*}$ & Mozambique & $8.627^{* *}$ \\
Namibia & $4.423^{* *}$ & Namibia & 0.796 \\
South Africa & $23.677^{* * *}$ & South Africa & 0.536 \\
Swaziland & $8.349^{* *}$ & Swaziland & 5.257 \\
Tanzania & 3.635 & Tanzania & 0.425 \\
Zambia & 0.623 & Zambia & 3.262 \\
Panel & $94.378^{*}$ & Panel & 69.049 \\
\hline
\end{tabular}

$*, * *$ and $* * *$ indicate significance at $0.1,0.05$ and 0.001 significance levels, respectively

Table 7. Granger causality between financial development (stability) and sustainable economic opportunity

\begin{tabular}{c|c|c|c}
\hline $\begin{array}{c}\text { H0: financial development (stability) does not } \\
\text { Granger cause sustainable economic opportunity }\end{array}$ & \multicolumn{2}{|c}{$\begin{array}{c}\text { H0: sustainable economic opportunity does not } \\
\text { Granger cause financial development (stability) }\end{array}$} \\
\hline Countries & Wald statistic & Countries & Wald statistic \\
\hline Angola & 2.439 & Angola & 1.742 \\
Botswana & $30.035^{* * *}$ & Botswana & 1.309 \\
DR Congo & $8.451^{* *}$ & DR Congo & $14.939^{* * * *}$ \\
Lesotho & 2.672 & Lesotho & $68.804^{* * *}$ \\
Madagascar & $16.370^{* * *}$ & Madagascar & $7.234^{*}$ \\
Malawi & 1.787 & Malawi & $11.989^{* * *}$ \\
Mauritius & $7.592^{* * *}$ & Mauritius & 2.594 \\
Mozambique & 1.883 & Mozambique & $6.382^{*}$ \\
Namibia & $4.826^{* *}$ & Namibia & 0.245 \\
South Africa & $70.341^{* * *}$ & South Africa & $41.103^{* * *}$ \\
Swaziland & 3.513 & Swaziland & 5.731 \\
Tanzania & $23.042^{* * *}$ & Tanzania & $49.592^{* * *}$ \\
Zambia & 0.244 & Zambia & $7.091^{* * *}$ \\
Panel & $161.827^{* *}$ & Panel & $190.694^{* *}$ \\
\hline
\end{tabular}

$*, * *$ and $* * *$ indicate significance at $0.1,0.05$ and 0.001 significance levels, respectively 
In Tables 8-12 below, the causality results for the relationship between financial development (overall index, access, depth, efficiency and stability, respectively) and ecological footprint at country and panel levels are reported. Again, the focus is on the outcomes from the overall financial development index. At country level, it is discovered that causality varies with different conditions. Significant Granger causality from overall financial development index to ecological footprint exists in DR Congo, Namibia and Swaziland. Significant one-way causality in the other direction exists in Mauritius and Mozambique. Significant feedback relationship exists in Lesotho, Madagascar, Malawi and South-Africa. At the panel level, one-way causality from overall financial development index to ecological footprint is found.

When the overall financial development index is disaggregated into its components, at country level, one-way causal effect is detected from financial access to ecological footprint in Angola, Mozambique, Namibia, Swaziland and Zambia, from ecological footprint to financial access in DRC, Mauritius and South Africa, from financial depth to ecological footprint in Botswana, DRC Congo, Madagascar and Mauritius, from ecological footprint to financial depth in Angola, Tanzania and Zambia, from financial efficiency to ecological footprint in Malawi, Mauritius and Tanzania, from ecological footprint to financial efficiency in Namibia and Swaziland, from financial stability to ecological footprint in DR Congo, Namibia, South Africa and Zambia, and from ecological footprint to financial stability in Lesotho. Bidirectional causal effects are also detected between financial access and ecological footprint in Madagascar and Malawi, between financial depth and ecological footprint in Lesotho, Malawi, Mozambique, Namibia and Swaziland, and between financial stability and ecological footprint in Malawi, Mauritius, Swaziland and Tanzania. At the panel level, causality is found running only from financial access to ecological footprint.

Table 8. Granger causality between financial development (index) and ecological footprint

\begin{tabular}{c|c|c|c}
\hline $\begin{array}{c}\text { H0: financial development (index) does not } \\
\text { Granger cause ecological footprint }\end{array}$ & \multicolumn{2}{|c}{$\begin{array}{c}\text { H0: ecological footprint does not Granger cause } \\
\text { financial development (index) }\end{array}$} \\
\hline Countries & Wald statistic & Countries & Wald statistic \\
\hline Angola & 5.431 & Angola & 2.187 \\
Botswana & 0.787 & Botswana & 1.756 \\
DR Congo & $3.212^{*}$ & DR Congo & 2.495 \\
Lesotho & $13.793^{* * *}$ & Lesotho & $2.804^{*}$ \\
Madagascar & $26.075^{* * *}$ & Madagascar & $11.904^{* * *}$ \\
Malawi & $13.907^{* * *}$ & Malawi & $14.675^{* * *}$ \\
Mauritius & 6.202 & Mauritius & $6.020^{* *}$ \\
Mozambique & 1.93 & Mozambique & $20.474^{* * *}$ \\
Namibia & $2.970^{* *}$ & Namibia & 0.002 \\
South-Africa & $11.230^{* * *}$ & South-Africa & $12.542^{* * * *}$ \\
Swaziland & $17.114^{* *}$ & Swaziland & 2.756 \\
Tanzania & 2.125 & Tanzania & 2.502 \\
Zambia & 2.709 & Zambia & 0.187 \\
Panel & $100.121^{*}$ & Panel & 2.756 \\
\hline
\end{tabular}

$*, * *$ and $* * *$ indicate significance at $0.1,0.05$ and 0.001 significance levels, respectively 
Table 9. Granger causality between financial development (access) and ecological footprint

\begin{tabular}{c|c|c|c}
\hline $\begin{array}{c}\text { H0: financial development (access) does not } \\
\text { Granger cause ecological footprint }\end{array}$ & \multicolumn{2}{|c}{$\begin{array}{c}\text { H0: ecological footprint does not Granger cause } \\
\text { financial development (access) }\end{array}$} \\
\hline Countries & Wald statistic & Countries & Wald statistic \\
\hline Angola & $8.930^{* * *}$ & Angola & 0.065 \\
Botswana & 0.787 & Botswana & 1.756 \\
DR Congo & 2.785 & DR Congo & $29.065^{* * *}$ \\
Lesotho & 0.712 & Lesotho & 1.639 \\
Madagascar & $26.075^{* * *}$ & Madagascar & $45.053^{* * *}$ \\
Malawi & $3.571^{*}$ & Malawi & $4.254^{* *}$ \\
Mauritius & 6.202 & Mauritius & $22.274^{* * *}$ \\
Mozambique & $4.263^{*}$ & Mozambique & 1.598 \\
Namibia & $3.354^{* *}$ & Namibia & 0.056 \\
South Africa & 2.407 & South Africa & $3.737^{*}$ \\
Swaziland & $19.896^{* * *}$ & Swaziland & 3.683 \\
Tanzania & 2.125 & Tanzania & 2.502 \\
Zambia & $2.871^{*}$ & Zambia & 0.261 \\
Panel & $92.743^{*}$ & Panel & 117.991 \\
\hline
\end{tabular}

$*$,** and *** indicate significance at $0.1,0.05$ and 0.001 significance levels, respectively

Table 10. Granger causality between financial development (depth) and ecological footprint

\begin{tabular}{c|c|c|c}
\hline $\begin{array}{c}\text { H0: financial development (depth) does not } \\
\text { Granger cause ecological footprint }\end{array}$ & \multicolumn{2}{|c}{$\begin{array}{c}\text { H0: ecological footprint does not Granger cause } \\
\text { financial development (depth) }\end{array}$} \\
\hline Countries & Wald statistic & Countries & Wald statistic \\
\hline Angola & 5.431 & Angola & $12.095^{* * *}$ \\
Botswana & $3.736^{* *}$ & Botswana & 1.543 \\
DR Congo & $3.212^{* *}$ & DR Congo & 2.495 \\
Lesotho & $13.793^{* * *}$ & Lesotho & $18.873^{* * *}$ \\
Madagascar & $11.585^{* * *}$ & Madagascar & 1.087 \\
Malawi & $13.907^{* * *}$ & Malawi & $7.756^{*}$ \\
Mauritius & $6.390^{*}$ & Mauritius & 5.853 \\
Mozambique & $27.401^{* * *}$ & Mozambique & $9.045^{* *}$ \\
Namibia & $69.097^{* * *}$ & Namibia & $25.824^{* * *}$ \\
South Africa & 1.787 & South Africa & 0.092 \\
Swaziland & $7.815^{* *}$ & Swaziland & $7.109^{*}$ \\
Tanzania & 5.558 & Tanzania & $9.794^{* * *}$ \\
Zambia & 1.658 & Zambia & $7.078^{* *}$ \\
Panel & 155.431 & Panel & 94.677 \\
\hline
\end{tabular}

$*, * *$ and $* * *$ indicate significance at $0.1,0.05$ and 0.001 significance levels, respectively 
Table 11. Granger causality between financial development (efficiency) and ecological footprint

\begin{tabular}{c|c|c|c}
\hline $\begin{array}{c}\text { H0: financial development (efficiency) does not } \\
\text { Granger cause ecological footprint }\end{array}$ & $\begin{array}{c}\text { H0: ecological footprint does not Granger cause } \\
\text { financial development (efficiency) }\end{array}$ \\
\hline Countries & Wald statistic & Countries & Wald statistic \\
\hline Angola & 1.421 & Angola & 0.064 \\
Botswana & 0.777 & Botswana & 0.836 \\
DR Congo & 0.916 & DR Congo & 0.682 \\
Lesotho & 0.622 & Lesotho & 2.385 \\
Madagascar & 3.430 & Madagascar & 3.433 \\
Malawi & $10.652^{* * *}$ & Malawi & 0.702 \\
Mauritius & $9.868^{* *}$ & Mauritius & 2.662 \\
Mozambique & 3.229 & Mozambique & 3.433 \\
Namibia & 1.046 & Namibia & $6.675^{* * *}$ \\
South Africa & 2.200 & South Africa & 0.170 \\
Swaziland & 6.413 & Swaziland & $18.066^{* * *}$ \\
Tanzania & $3.077^{*}$ & Tanzania & 0.231 \\
Zambia & 1.462 & Zambia & 2.439 \\
Panel & 51.938 & Panel & 45.391 \\
\hline
\end{tabular}

$*, * *$ and $* * *$ indicate significance at $0.1,0.05$ and 0.001 significance levels, respectively

Table 12. Granger causality between financial development (stability) and ecological footprint

\begin{tabular}{c|c|c|c}
\hline $\begin{array}{c}\text { Ho: financial development (stability) does not } \\
\text { Granger cause ecological footprint }\end{array}$ & $\begin{array}{c}\text { H0: ecological footprint does not Granger cause } \\
\text { financial development (stability) }\end{array}$ \\
\hline Countries & Wald statistic & Countries & Wald statistic \\
\hline Angola & 1.087 & Angola & 8.232 \\
Botswana & 0.514 & Botswana & 3.306 \\
DR Congo & $20.352^{* * *}$ & DR Congo & 5.033 \\
Lesotho & 4.279 & Lesotho & $10.230^{* * *}$ \\
Madagascar & 6.235 & Madagascar & 1.369 \\
Malawi & $23.191^{* * *}$ & Malawi & $10.934^{* *}$ \\
Mauritius & $11.913^{* * *}$ & Mauritius & $18.154^{* * *}$ \\
Mozambique & 1.930 & Mozambique & 3.768 \\
Namibia & $2.970^{* *}$ & Namibia & 0.002 \\
South Africa & $11.230^{* *}$ & South Africa & 4.676 \\
Swaziland & $17.114^{* * * *}$ & Swaziland & $9.811^{* *}$ \\
Tanzania & $28.073^{* * *}$ & Tanzania & $9.970^{* *}$ \\
Zambia & $25.873^{* * *}$ & Zambia & 3.324 \\
Panel & 134.210 & Panel & 70.200 \\
\hline
\end{tabular}

$*, * *$ and $* * *$ indicate significance at $0.1,0.05$ and 0.001 significance levels, respectively 
With respect to the causal relations between sustainable economic opportunity and ecological footprint, as reported in Table 13, one-way causal effect from sustainable economic opportunity to ecological footprint is detected in Madagascar, Mozambique, Namibia and Tanzania at the country level. One-way causality in the opposite direction is however detected in Mauritius while a feedback relationship between both variables is uncovered in Angola, South Africa and Swaziland.

Table 13. Granger causality between sustainable economic opportunity and ecological footprint

\begin{tabular}{c|c|c|c}
\hline $\begin{array}{c}\text { H0: sustainable economic opportunity does not } \\
\text { Granger cause ecological footprint }\end{array}$ & $\begin{array}{c}\text { H0: ecological footprint does not Granger cause } \\
\text { sustainable economic opportunity }\end{array}$ \\
\hline Countries & Wald statistic & Countries & Wald statistic \\
\hline Angola & $12.593^{* * *}$ & Angola & $6.507^{*}$ \\
Botswana & 0.654 & Botswana & 0.141 \\
DR Congo & 2.216 & DR Congo & 0.403 \\
Lesotho & 0.368 & Lesotho & 2.421 \\
Madagascar & $33.985^{* * *}$ & Madagascar & 3.161 \\
Malawi & 3.651 & Malawi & 6.493 \\
Mauritius & 4.304 & Mauritius & $196.026^{* * *}$ \\
Mozambique & $17.640^{* * *}$ & Mozambique & 4.324 \\
Namibia & $5.084^{* *}$ & Namibia & 0.194 \\
South Africa & $4.013^{* *}$ & South Africa & $5.203^{* *}$ \\
Swaziland & $14.688^{* * * *}$ & Swaziland & $133.019^{* * *}$ \\
Tanzania & $4.117^{* *}$ & Tanzania & 0.613 \\
Zambia & 3.981 & Zambia & 2.074 \\
Panel & $103.569^{* * *}$ & Panel & 351.836 \\
\hline
\end{tabular}

$*, * *$ and $* * *$ indicate significance at $0.1,0.05$ and 0.001 significance levels, respectively

\section{Discussion}

Findings from this study bring to the fore some interesting issues. First, the very ambitious agenda set by the SADC at inception include amongst others; regional integration, evolution of common political values, systems and institutions, achievement of complementarity between national and regional programmes and strategies, interdependence among member states, and strengthening and consolidation of historical, social and cultural affinities and links among people of the region. The presence of cross-sectional dependence in the region shows that the regional bloc has succeeded to a great extent in achieving these goals. The presence of country-specific heterogeneity however suggests that the region still has a long way to go before full integration is achieved. This is further confirmed by the dissimilar patterns of causality noticeable across the SADC.

Second, the dissimilar patterns of causality also suggest that a one size fits all approach to dealing with issues surrounding the interaction between financial development, sustainable economic opportunity and ecological footprint is not feasible in the SADC. In places where causality runs from financial development to sustainable 
economic opportunity, the financial system is able to stimulate the economy (supplyleading theory). As for countries where causality runs in the opposite direction, the financial system simply responds to improvements in the economy (demand-following theory). In countries where causality runs in both directions, a vicious cycle in which financial development triggers improvements in the economy which in turn further triggers financial development is experienced. In countries where no significant causality is detected, the neutrality theory holds. The economy cannot be improved through financial development neither can better economic performance drive financial development.

Third, it is also quite significant that the dimensions of financial development (access, depth, efficiency and stability) that are causally related to sustainable economic opportunity vary from country to country.

Fourth, concerning the relationship between sustainable economic opportunity and ecological footprint, the energy-led growth hypothesis holds true in countries where causality is detected from ecological footprint to sustainable economic opportunity. In such countries, energy is a necessary production factor and expansion of energy use will improve the economy, whereas in countries where causality is from sustainable economic opportunity ecological footprint, the conservation hypothesis holds true. In such places, energy plans may be implemented without the impacts on the economy.

\section{Conclusion}

In this paper, causal relationship between financial development, sustainable economic opportunity and ecological footprint in SADC countries during the period during the period 2000-2016 was examined. The use of bootstrap panel Granger causality tests of Emirmahmutoglu and Kose (2011), the adoption of ecological footprint, a multidimensional indicator of environmental condition, the introduction of sustainable economic opportunity and the consideration of various dimensions of financial development-financial access, financial depth, financial efficiency and financial stability-as well as an aggregate index of these 4 measures represent the main contribution of this paper. The empirical results indicate the following; first, that causality between financial development, sustainable economic opportunity and ecological footprint varies across countries with different conditions, and leads to the conclusion that SADC countries are heterogeneous in nature.

Second, that financial development causally affects sustainable economic opportunity. This supports the findings of Liang and Jian-Zhou (2006), Ang and McKibbin (2007), Panopoulou (2009), and Li et al. (2015). All these researches have revealed that financial development supports economic growth through channeling of credits. For example, Li et al. (2015), while investigating the relationship between financial development, environmental quality and economic growth in 102 countries, clearly indicated that financial development has an effect on economic growth and could be used in the production function of economic models, with sustainable economic opportunity being a measure of economic performance.

That financial development causally affects ecological footprint aligns with the position of Tamazian et al. (2009) and Charfeddine and Khediri (2016). Extant literature suggests that financial sector and the environment may be positively or negatively correlated. On one hand, a well-developed financial sector may assist the energy sector in adopting more efficient, ecofriendly technologies that help lower environmental 
degradation (Charfeddine and Khediri, 2016). Financial development may also cause improvements in the environment through funding of environmental projects at reduced funding costs (Tamazian et al., 2009).

Third, that sustainable economic opportunity causally affects ecological footprint. This is in agreement with the conclusions reached by Jensen (1996) that economic activity affects environmental conditions. Economic activities may also lead to increase in manufacturing activities, resulting in greater industrial pollution and environmental degradation (Jensen, 1996). The findings of Jensen (1996) is hung on the pollution haven hypothesis that industries that produce increased pollution are most likely to move to environments with flexible regulations on environmental pollution.

\section{Policy recommendations}

On the basis of the findings made in this study, the following policy recommendations are made:

In SADC countries where the supply-leading theory is confirmed, policy makers need to give more attention to political, legal and regulatory determinants of financial development since financial development can be used as a tool for achieving sustainable economic development. It will be in the interest of such countries to introduce modern financial institutions, especially depository and investment institutions that will stimulate financial services in terms of access, depth, efficiency and stability. Furthermore, each country should focus mainly on improving the dimensions of financial development (access, depth, efficiency or stability) that causally affect their sustainable economic opportunity.

Policy makers in SADC countries where the demand-following theory is confirmed need to quickly come to the realization that all efforts directed towards financial system development will not be worthwhile in the long-run, and more effort should instead be directed toward achieving a better economy.

In SADC countries where the energy-led hypothesis is confirmed, energy conservation policies designed to reduce greenhouse gas emissions to combat global warming may be counterproductive because they harm the economy. On the other hand, in SADC countries where the conservation hypothesis holds, energy conservation policies may be implemented without significant impact on economic performance.

\section{REFERENCES}

[1] Acar, S., Asici, A. A. (2017): Nature and economic growth in Turkey: what does ecological footprint imply? - Middle East Development Journal 9(1): 101-115.

[2] Acemoglu, D., Wolitzky, A. (2015): Sustaining Cooperation: Community Enforcement vs. Specialized Enforcement (No. w21457). - National Bureau of Economic Research, Cambridge, MA. DOI: 10.3386/w21457.

[3] Al-Mulali, U., Saboori, B. and Ozturk, I. (2015): Investigating the environmental Kuznets curve hypothesis in Vietnam. - Energy Policy 76: 123-131.

[4] Al-Yousif, Y. K. (2002): Financial development and economic growth: another look at the evidence from developing countries. - Review of Financial Economics 11(2): 131150 .

[5] Ang, J. B. (2008): What are the mechanisms linking financial development and economic growth in Malaysia? - Economic Modelling 25(1): 38-53. 
[6] Ang, J. B., McKibbin, W. J. (2007): Financial liberalization, financial sector development and growth: evidence from Malaysia. - Journal of Development Economics 84(1): 215233. DOI: 10.1016/j.jdeveco.2006.11.006.

[7] Apergis, N., Ozturk, I. (2015): Testing environmental Kuznets curve hypothesis in Asian countries. - Ecological Indicators 52: 16-22.

[8] Azam, M., Khan, A. Q. (2016): Testing the Environmental Kuznets Curve hypothesis: A comparative empirical study for low, lower middle, upper middle and high income countries. - Renewable and Sustainable Energy Reviews 63: 556-567.

[9] Baabou, W., Grunewald, N., Ouellet-Plamondon, C., Gressot, M. and Galli, A. (2017): The ecological footprint of Mediterranean cities: awareness creation and policy implications. - Environmental Science \& Policy 69: 94-104.

[10] Bojanic, A. N. (2012): The impact of financial development and trade on the economic growth of Bolivia. - Journal of Applied Economics 15(1): 51-70.

[11] Breusch, T. S. and Pagan, A. R. (1980): The Lagrange multiplier test and its applications to model specification in econometrics. - The Review of Economic Studies 47(1): 239253.

[12] Chang, M. C. (2015): Room for improvement in low carbon economies of G7 and BRICS countries based on the analysis of energy efficiency and environmental Kuznets curves. Journal of Cleaner Production 99: 140-151.

[13] Chang, T., Cheng, S. C., Pan, G., and Wu, T. P. (2013): Does globalization affect the insurance markets? Bootstrap panel Granger causality test. - Economic Modelling 33: 254-260.

[14] Charfeddine, L., Khediri, K. B. (2016): Financial development and environmental quality in UAE: Cointegration with structural breaks. - Renewable and Sustainable Energy Reviews 55: 1322-1335.

[15] Emirmahmutoglu, F., Kose, N. (2011): Testing for Granger causality in heterogeneous mixed panels. - Economic Modelling 28(3): 870-876.

[16] Feng, Y., Chen, H., Tang, J. (2018): The impacts of social responsibility and ownership structure on sustainable financial development of China's energy industry. Sustainability 10(2): 301. DOI: 10.3390/su10020301.

[17] Fisher, A. G. (1932): Fundamental presupposition for successful economic planning. Economic Record 8(3): 88-98. DOI: 10.1111/j.1475-49321932.tb00737. x.

[18] Gill, A. R., Viswanathan, K. K., Hassan, S. (2017): A test of environmental Kuznets curve (EKC) for carbon emission and potential of renewable energy to reduce greenhouses gases (GHG) in Malaysia. - Environment, Development and Sustainability 20(3): 1-12. DOI: 10.1016/j.rser.2017.05.247.

[19] Global Footprint Network National Footprint Accounts. (2018): https://data.footprintnetwork.org.

[20] Huang, Y., Wang, X. (2017): Building an efficient financial system in China: a need for stronger market discipline. - Asian Economic Policy Review 12(2): 188-205. DOI: 10.1111/aepr.12173.

[21] Jensen, V. M. (1996): Trade and Environment: The Pollution Haven Hypothesis and the Industrial Flight Hypothesis; Some Perspectives on Theory and Empirics. - University of Oslo, Centre for Development and the Environment, Oslo.

[22] Kang, Y. Q., Zhao, T., Yang, Y. Y. (2016): Environmental Kuznets curve for CO2 emissions in China: a spatial panel data approach. - Ecological Indicators 63: 231-239.

[23] Körner, T., Schnabel, I. (2009): When do state-owned banks hamper economic growth? 7th Workshop on "Money, Banking and Financial Markets," Halle Institute for Economic Research.

[24] Lau, L. S., Choong, C. K., Eng, Y. K. (2014): Investigation of the environmental Kuznets curve for carbon emissions in Malaysia: Do foreign direct investment and trade matter? Energy Policy 68: 490-497. 
[25] Li, S., Zhang, J., Ma, Y. (2015): Financial development, environmental quality and economic growth. - Sustainability 7(7): 9395-9416.

[26] Li, T., Wang, Y., Zhao, D. (2016): Environmental Kuznets curve in China: new evidence from dynamic panel analysis. - Energy Policy 91: 138-147.

[27] Liang, Q., Jian-Zhou, T. (2006): Financial development and economic growth: Evidence from China. - China Economic Review 17(4): 395-411.

[28] Mo Ibrahim Foundation (2018): http://mo.ibrahim.foundation.

[29] Mukhopadhyay, B., Pradhan, R. P., Feridun, M. (2011): Finance-growth nexus revisited for some Asian countries. - Applied Economics Letters 18(16): 1527-1530.

[30] Onafowora, O. A., Owoye, O. (2014): Bounds testing approach to analysis of the environment Kuznets curve hypothesis. - Energy Economics 44: 47-62.

[31] Panopoulou, E. (2009): Financial variables and euro area growth: A non-parametric causality analysis. - Economic Modelling 26(6): 1414-1419.

[32] Pesaran, M. H. (2004): General Diagnostic Tests for Cross Section Dependence in Panels. - CESifo Working Paper Series No. 1229; IZA Discussion Paper No. 1240. http://ssrn.com/abstract $=572504$.

[33] Pesaran, M. H., Yamagata, T. (2008): Testing slope homogeneity in large panels. Journal of Econometrics 142(1): 50-93.

[34] Pradhan, R. P., Dasgupta, P., Samadhan, B. (2013): Finance, development and economic growth in BRICS: A panel data analysis. - Journal of Quantitative Economics 11(1-2): 308-322.

[35] Pradhan, R. P., Tripathy, S., Chatterjee, D., Zaki, D. B., Mukhopadhyay, B. (2014): Development of banking sector and economic growth: The ARF experience. - Decision 41(3): 245-259.

[36] Rousseau, P. L., Wachtel, P. (2011): What is happening to the impact of financial deepening on economic growth? - Economic Inquiry 49(1): 276-288. DOI: $10.1111 /$ j.1465-7295.2009. 00197.

[37] Seyoum, M., Wu, R., Lin, J. (2014): Foreign direct investment and trade openness in Sub-Saharan economies: A panel data granger causality analysis. - South African Journal of Economics 82(3): 402-421.

[38] Sofia, A., Ghulam, S., Zakir, H. (2011): Relationship between financial sector development and sustainable economic development: time series analysis from Pakistan. - International Journal of Economics and Finance 3(1). DOI: 10.5539/ijef. v3n1p262.

[39] Southern African Development Community (2018): https://www.sadc.int/aboutsadc/overview/sadc-facts-figures.

[40] Swamy, P. A. (1970): Efficient inference in a random coefficient regression model. Econometrica: Journal of the Econometric Society 311-323.

[41] Tamazian, A., Chousa, J. P., Vadlamannati, K. C. (2009): Does higher economic and financial development lead to environmental degradation: evidence from BRIC countries. - Energy Policy 37(1): 246-253.

[42] Tang, C. F., Tan, B. W. (2015): The impact of energy consumption, income and foreign direct investment on carbon dioxide emissions in Vietnam. - Energy 79: 447-454.

[43] Toda, H. Y., Yamamoto, T. (1995): Statistical inference in vector auto regressions with possibly integrated processes. - Journal of Econometrics 66(1-2): 225-250.

[44] Wackernagel, M., Schulz, N. B., Deumling, D., Linares, A. C., Jenkins, M., Kapos, V., Randers, J. (2002): Tracking the ecological overshoot of the human economy. Proceedings of the National Academy of Sciences 99(14): 9266-9271.

[45] Wolde-Rufael, Y. (2009): Re-examining the financial development and economic growth nexus in Kenya. - Economic Modelling 26(6): 1140-1146.

[46] World Economic Forum (2012): World economic forum global competitiveness report. http://www3.weforum.org/docs/WEF_GlobalCompetitivenessReport_2012-13.pdf. 